\title{
ANGIOTENSIN CONVERTING ENZYME INHIBITORY PEPTIDE FRACTIONS FROM TIBET WILD PEACH KERNEL PROTEIN HYDROLYSATES
}

\author{
Y. YANG ${ }^{\mathrm{a}}, \mathrm{A} . \mathrm{LI}^{\mathrm{a}}, \mathrm{Z} . \mathrm{ZHONG}{ }^{\mathrm{b}}$ and M. XIE \\ ${ }^{a}$ College of Food Science and Engineering, Central South University of Forestry and Technology, Shaoshan South \\ road No.489, 410004 Changsha. China \\ ${ }^{\mathrm{b}}$ College of Food Science, Tibet Agricultural and Animal Husbandry University, Yucai west road No.100, 860000 \\ Linzhi. China
}

(Received: 10 April 2019; accepted: 4 June 2019)

\begin{abstract}
In this study, the peach kernel proteins were extracted and treated with alkaline proteinase to generate peach kernel protein hydrolysate (PKH), which showed angiotensin converting enzyme (ACE) inhibition activity. The hydrolysate was separated into four fractions and their anti-ACE activities were investigated. Our results showed that all PKHs had anti-ACE activity, and the lowest molecular weight fraction PKH4 had the highest ACE inhibitory activity. Lineweaver-Burk plots illustrated that the inhibition types of PKH3 and PKH4 were non-competitive. The $\mathrm{K}_{\mathrm{i}}$ of PKH4 was lower than $\mathrm{K}_{\mathrm{i}}$ of PKH3; suggesting PKH4 had high affinity to ACE. Amino acid composition analysis showed that the best anti-ACE peptide PKH4 possessed high levels of hydrophobic amino acids, branched-chain amino acids, and aromatic amino acids. In summary, our findings demonstrated that high anti-ACE activity is negatively related to the size of the PKHs and possibly the composition of amino acids, and the PKH4 was the best ACE inhibitor. Further, peach kernel peptides can be developed as a functional food for patients with hypertension.

Keywords: peach kernel, protein hydrolysate, angiotensin converting enzyme, ACE, hypertension
\end{abstract}

Hypertension causes cardiovascular diseases and is a worldwide severe public health issue. About $25 \%$ of adults suffer from hypertension at the present time, and the percentage would achieve $60 \%$ in 2025 (Coluins et al., 2016). Angiotensin converting enzyme (ACE) plays a key role in renin-angiotensin and kallikrein-kinin system to increase blood pressure. ACE catalyzes the conversion of angiotensin I to angiotensin II (potential vasoconstrictive action) and inactivates bradykinin (vasodilative action) (SHOBAKo et al., 2018). Inhibition of ACE activity is one of the main therapies to treat hypertension. Commonly used ACE inhibitors such as captopril, enalapril, and naproxen are synthetic and usually cause side effects like cough, dysgeusia, rash, angioneurotic edema, etc. Different from synthetic inhibitors, foodderived peptides such as from cheese (RAFIQ et al., 2017), fish (LuO et al., 2017), and bean (LuNA-VITAL et al., 2015) have been demonstrated to be ACE inhibitors with advantages of safety, fewer side effects, easy to absorb, etc. Many peptides from food protein hydrolysates have been identified possessing bioactivities such as antioxidant, anti-diabetics, antiinflammatory as well as anti-hypertension, etc.

China is the largest peach producer over the world (IORDĂNESCU et al., 2015). In the process of peach production, most peach kernels are discarded as waste. In traditional Chinese medicine, peach kernel is used to treat hypertension with the function to promote blood circulation and remove blood stasis (WANG et al., 2015). What is more, amygdalin in peach

\footnotetext{
* To whom correspondence should be addressed.

Phone: +86-13787319195; e-mail:912336799@qq.com
} 
kernel has the ability to inhibit the growth of human colon cancer cells in vitro (CASSIEM \& DE Kock, 2019). Recent studies demonstrated that peach kernel had cardiovascular protection activities (YI et al., 2013). Particularly, ZHU and co-workers (2015) reported that peach kernel peptides had ACE and rennin inhibitory activities. Similarly, MIRZAPOUR and co-workers (2017) proved that wild almond peptides effectively inhibited ACE activity.

Tibet wild peach tree is tall and grows in areas of high sea level. It is widely distributed in the southeast of Tibet, particularly in low-lying and humid areas such as river valley or next to the village in the Linzhi Region of Tibet. The annual yield of peach is about 5 million kilograms. In addition to be consumed by local people in small amount, most of the peaches are returned to nature as waste. To find a better way of using the Tibet wild peaches, we investigated the potential use of the peach kernel protein hydrolysates as ACE inhibitor.

\section{Materials and methods}

\subsection{Preparation of peach kernel protein hydrolysate}

Seven grams peach kernel protein lyophilized powder was dispersed in $200 \mathrm{ml}$ deionized water $(3.5 \%, \mathrm{w} / \mathrm{v})$, the $\mathrm{pH}$ was adjusted to 10 at room temperature, and then the sample was heated to $45^{\circ} \mathrm{C}$ prior to the addition of alkaline proteinase, according to the ratio of enzyme to substrate (E/S) of $4200 \mathrm{U} \mathrm{g}^{-1}$. Enzymatic hydrolysis was performed at $45^{\circ} \mathrm{C}$ for $5 \mathrm{~h}$. After hydrolysis, the enzymatic reaction was stopped by boiling for $20 \mathrm{~min}$ in a water bath. Then the hydrolysate was centrifuged at 8000 r.p.m. for $20 \mathrm{~min}$ at $4{ }^{\circ} \mathrm{C}$. After hydrolysis with alkaline proteinase, the peach kernel hydrolysate was filtered consecutively using an ultrafiltration cup (MSC300, Shanghai Mosu Science Equipment Co., Ltd.) through three ultrafiltration membranes with molecular weight (MW) cut-off of 10, 5, and $3 \mathrm{kDa}$. Four fractions, PKH1 (MW>10 kDa), PKH2 (MW 5-10 kDa), PKH3 (MW 3-5 kDa), and PKH4 $(\mathrm{MW}<3 \mathrm{kDa})$, were obtained. These fractions were lyophilized and stored at $-20^{\circ} \mathrm{C}$ until use.

\subsection{SDS-PAGE analysis of PKP and PKHS}

Peach kernel protein was dissolved in $80 \mu \mathrm{l}$ of $8 \mathrm{M}$ urea solution and peach kernel enzymatic hydrolysate was dissolved in deionized water, and then $20 \mu 1$ SSDS loading buffer was added, making the concentration of both samples $10 \mathrm{mg} \mathrm{ml}^{-1}$. Electrophoresis was carried out as described by LAEMmLI (1970) with some modifications. The resolving gel and stacking gel were $15 \%$ and $4 \%$, respectively. The separation process was carried out at $160 \mathrm{~V}$ for $50 \mathrm{~min}$. Gel was fixed and stained with a solution containing $0.125 \%(\mathrm{w} / \mathrm{v})$ Coomassie Blue R-250, $50 \%(\mathrm{v} / \mathrm{v})$ methanol, and 10\% (v/v) acetic acid. The gel was detained with a solution consisting of $25 \%(\mathrm{v} / \mathrm{v})$ methanol and $10 \%(\mathrm{v} / \mathrm{v})$ acetic acid. The molecular weights of peach kernel protein and hydrolysate were determined with reference to the relative migration of Page-Ruler unstained protein standards.

\subsection{ACE inhibitory activity assay}

The ACE inhibitory activity was measured according to the method of ARISE and co-workers (2017) with some modification. Eighty microlitres of sample (dissolved in $50 \mathrm{mM}$ Tris- $\mathrm{HCl}$ buffer containing $0.3 \mathrm{M} \mathrm{NaCl}, \mathrm{pH} 7.5)$ was mixed with $20 \mu \mathrm{l} \mathrm{ACE}\left(0.2 \mathrm{U} \mathrm{ml}^{-1}\right)$ and $200 \mu \mathrm{l}$ FAPGG (dissolved in $50 \mathrm{mM}$ Tris- $\mathrm{HCl}$ buffer). Then, absorbance at $345 \mathrm{~nm}\left(\Delta \mathrm{A}_{345 \mathrm{~nm}}\right)$ was 
recorded at $0 \mathrm{~min}$ and $40 \mathrm{~min}$ at room temperature. In blank, buffer was used to replace sample. The ACE inhibition was calculated by the equation below:

$$
\text { ACE inhibition, } \%=\left(1-\frac{\Delta A_{\text {inhibitor }}}{\Delta A_{\text {blank }}}\right) \times 100 \text {. }
$$

The $\mathrm{IC}_{50}$ value was defined as the concentration of peptides that inhibited 50\% ACE activity.

\subsection{Determination of kinetic parameters of ACE inhibition peptides}

The kinetics of ACE inhibition was determined with $0.125,0.250,0.500$, and $1.000 \mathrm{mM}$ FAPGG as substrate. Substrate $(200 \mu \mathrm{l})$ was mixed with $20 \mu \mathrm{l} \mathrm{ACE}\left(0.2 \mathrm{U} \mathrm{ml}^{-1}\right)$ in the absence or presence of $80 \mu \mathrm{l}$ of 0.1 and $0.2 \mathrm{mg} \mathrm{m}^{-1} \mathrm{PKH} 3$ and PKH4. The ACE activity was determined as above. The $\mathrm{V}_{\mathrm{m}}$ and $\mathrm{K}_{\mathrm{m}}$ were determined from the Lineweaver-Burk plots. Finally, inhibition constant $\left(\mathrm{K}_{\mathrm{i}}\right)$ was calculated as the $\mathrm{x}$-axis intercept from a plot of the slope of the Lineweaver-Burk lines against peptide concentration (GIRGIH et al., 2014).

\subsection{Amino acid composition analysis}

The amino acid compositions and amounts of peach kernel hydrolysate (PKH) and various ultrafiltrated fractions were determined by using high-speed amino acid analyzer (L-8900, Hitachi) according to the method of BIDLINGMEYER and co-workers (1984). Tryptophan level was determined after alkaline hydrolysis, in accordance with the method of LOMBARD and DERANGE (1965).

\subsection{Statistical analysis}

All experiments were carried out in duplicate or triplicate. The data were analyzed by using one-way analysis of variance (ANOVA). Duncan's multiple range test was used to determine the statistically significant differences $(\mathrm{P}<0.01)$. The SPSS statistical software package Version 17 was used.

\section{Results and discussion}

\subsection{Generation of peptide hydrolysates of peach kernel proteins}

SDS-PAGE was used to characterize the molecular weight of peach kernel proteins and PKHs. As shown in Figure 1, total peach kernel proteins (lane PKP) showed 6 major bands on SDS-PAGE. The sizes of these bands were $86 \mathrm{kDa}, 47 \mathrm{kDa}, 36 \mathrm{kDa}, 28 \mathrm{kDa}, 17 \mathrm{kDa}$, and $12 \mathrm{kDa}$. The most abundant protein bands had the sizes of 47, 36, and $28 \mathrm{kDa}$ (Fig. 1). After alkaline proteinase treatment, these proteins were digested to smaller proteins and peptides with sizes less than $15 \mathrm{kDa}$. The sizes of the three major digested bands were around 8,12 , and $15 \mathrm{kDa}$ (Fig. 1, lane PKH). These data indicated that alkaline proteinase is effective in degrading peach kernel proteins.

\subsection{ACE inhibitory activity of PKHs}

To test whether PKHs had ACE inhibitory activity, different concentrations of PKHs were incubated with rabbit ACE and the substrate, and ACE activity was determined. As shown in 
Figure 2, total PKH inhibited ACE activity. This inhibition was dose dependent with a two stage property. When total PKH was less than $0.4 \mathrm{mg} \mathrm{ml}^{-1}$, it inhibited ACE activity rapidly up to $20 \%$; then a linear inhibitory property was observed up to $2 \mathrm{mg} \mathrm{ml}^{-1}$ of $\mathrm{PKH}$, and the maximum inhibition was about $60 \%$. This two-stage inhibition phenomenon was also seen with size fractioned PKHs and the control inhibitor captopril (Fig. 2).

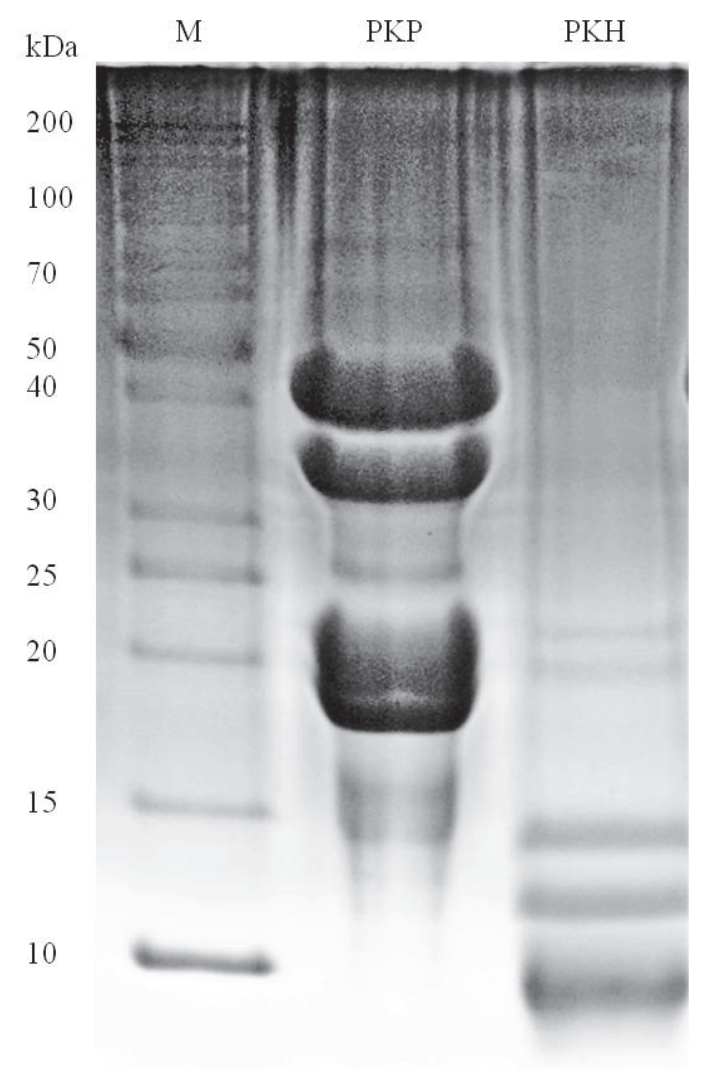

Fig. 1. SDS-PAGE analysis of peach kernel proteins and alkaline proteinase hydrolysate. M: protein standard marker; PKP: peach kernel proteins; PKH: total peach kernel proteins hydrolysates obtained by hydrolysis with alkaline proteinase

The $\mathrm{IC}_{50}$ values are listed in Table 1 . The $\mathrm{IC}_{50}$ value of captopril was $1.627 \times 10^{-6} \mathrm{mg} \mathrm{ml}^{-1}$, while the $\mathrm{IC}_{50}$ values were $0.082,0.136,0.329,1.116$, and $1.486 \mathrm{mg} \mathrm{ml}^{-1}$ for the PKH4 (MW<3 kDa), PKH3 (MW 3-5 kDa), PKH2 (MW 5-10 kDa), PKH1 (MW>10 kDa), and total $\mathrm{PKH}$ fractions, respectively. The $\mathrm{IC}_{50}$ value of PKH4 was about 1.66 times lower than that of PKH3, and even about 18 times lower than that of PKH. These results revealed that ACE inhibitory activity of PKHs are negatively related to the size of the PKHs (Pearson's $r^{2}$ $=-0.945)$, i.e., smaller size of PKH had higher ACE inhibition activity. PKH4 (MW<3 kDa) had the highest ACE inhibitory power. These results were in agreement with some previous studies. For instance, in studies of BETANCUR-ANCONA and co-workers (2015), both IC $_{50}$ values 
of the highest mass peptide fractions from Phaseolus lunatus and Phaseolus vulgaris were higher than the $\mathrm{IC}_{50}$ values of the lowest mass fractions. Similar results were reported for bambara groundnut protein hydrolysate (ARISE et al., 2017) and wild almond protein hydrolysate (MirzAPOUR et al., 2017). Thus, our results and results from other studies are in agreement that low molecular weight peptides have higher ACE inhibitory activity.
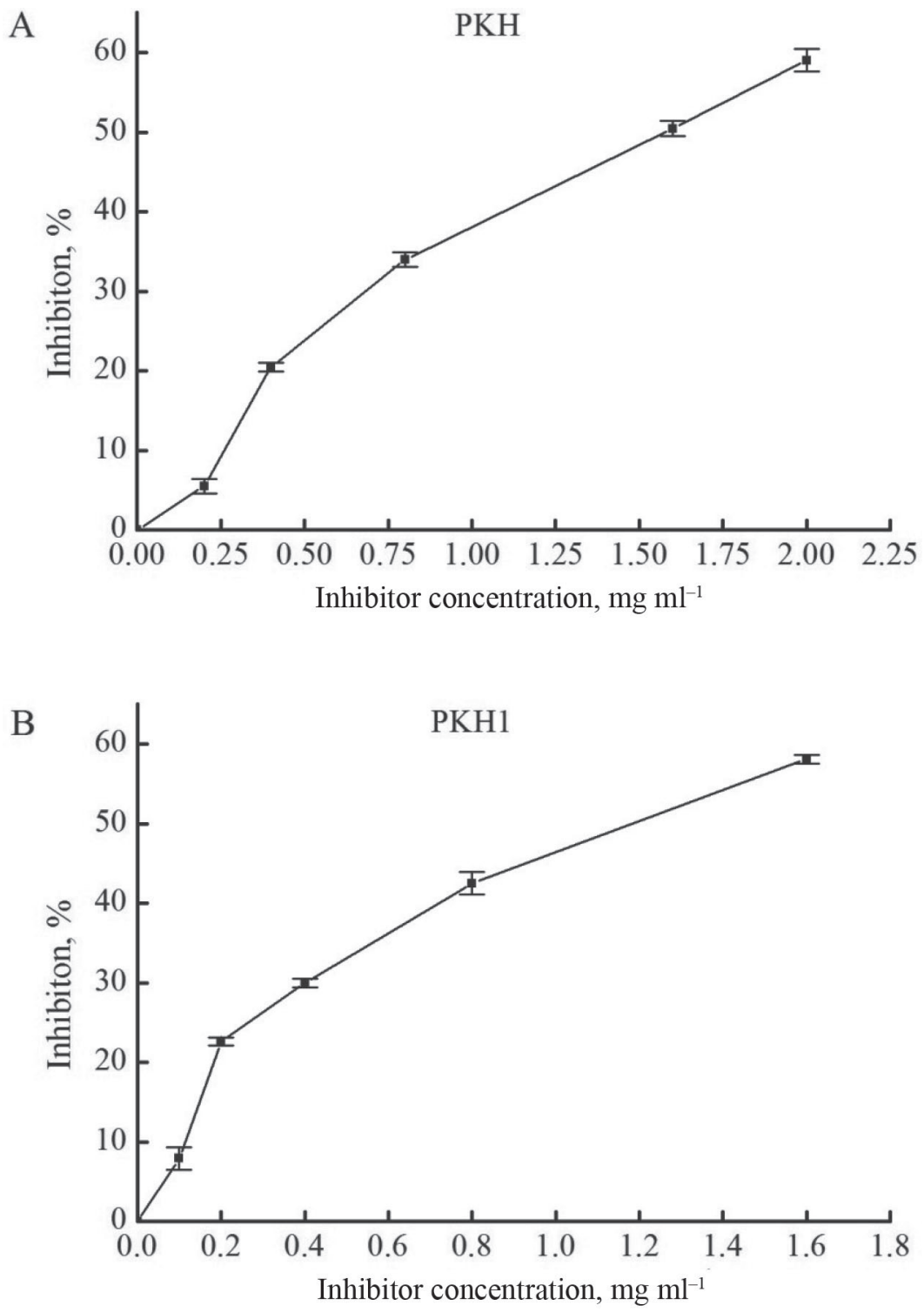

Fig. 2. Dose dependent effects of different peach kernel peptide factions and Captopril on Angiotensin converting enzyme. PKH: total peach kernel protein hydrolysates; PKH1: MW>10 kDa; PKH2: MW 5-10 kDa;

PKH3: MW 3-5 kDa; PKH4: MW<3 kDa 

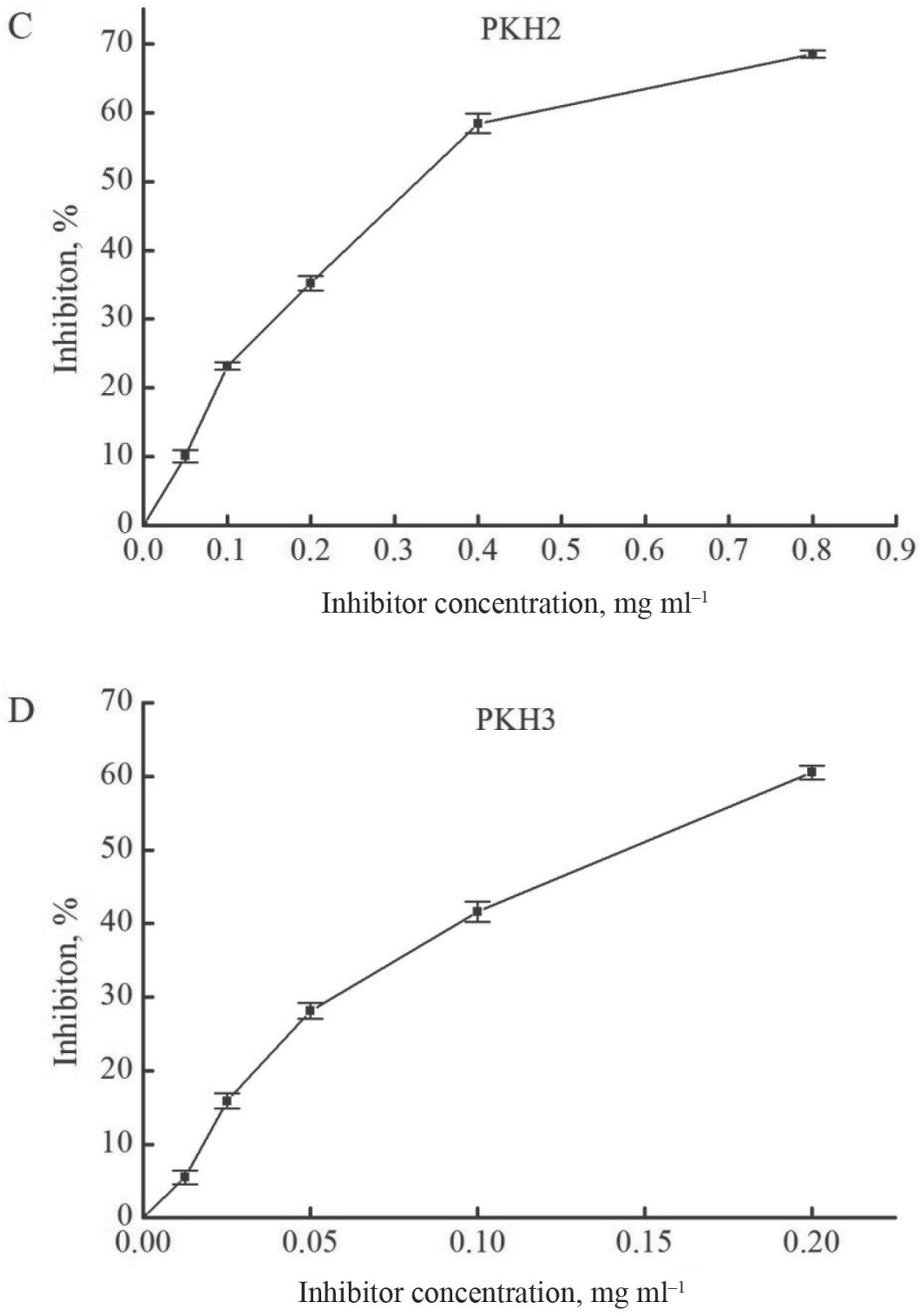

Fig. 2. Cont 

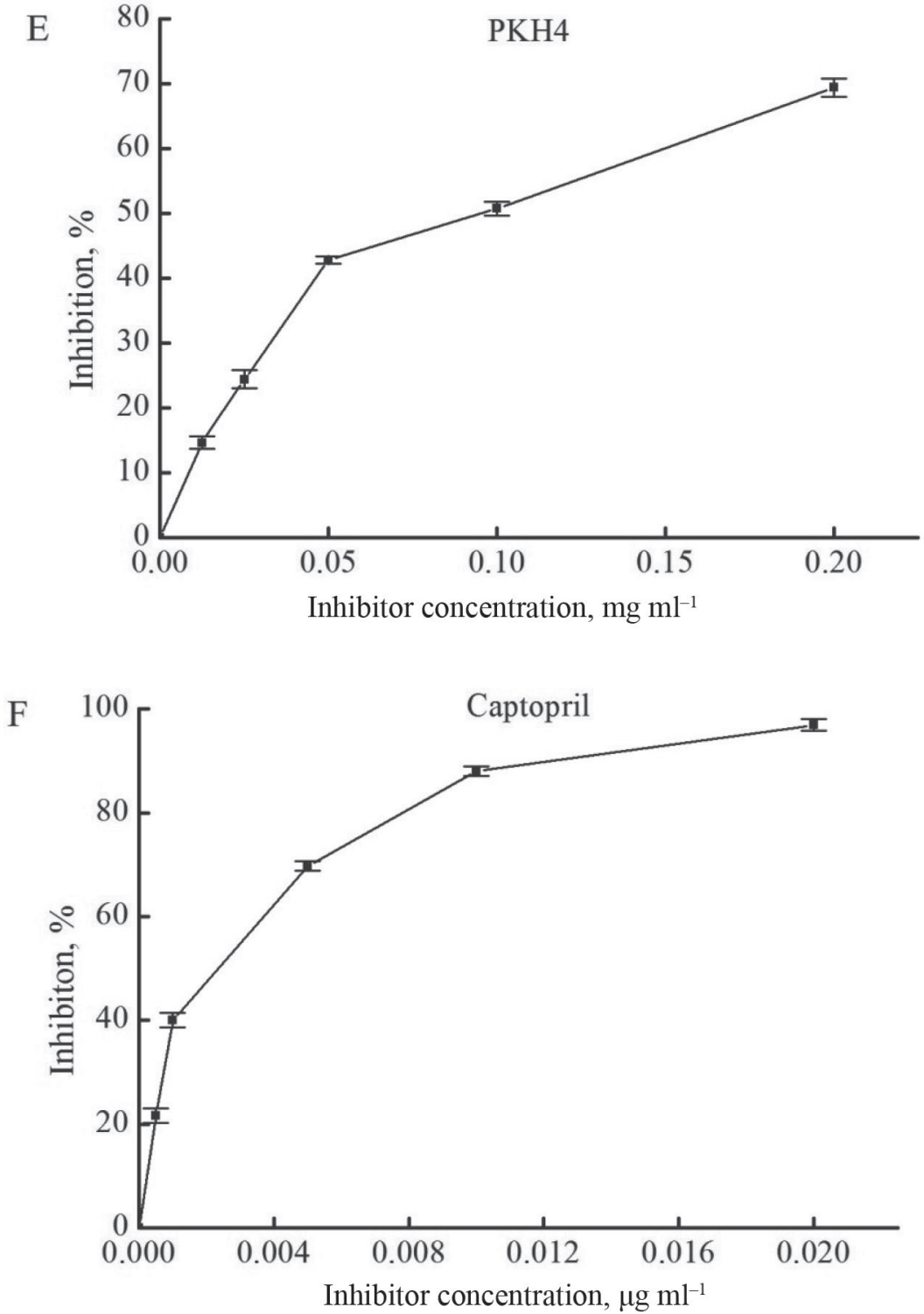

Fig. 2. Cont 
Table 1. Tibet wild peach kernel protein hydrolysates and their anti-ACE property

\begin{tabular}{lcc}
\hline Fraction & Description & $\mathrm{IC}_{50}$ value $\left(\mathrm{mg} \mathrm{ml}^{-1}\right)$ \\
\hline PKH & total hydrolysate & $1.486 \pm 0.023^{\mathrm{f}}$ \\
PKH1 & $\mathrm{MW}>10 \mathrm{kDa}$ & $1.116 \pm 0.045^{\mathrm{e}}$ \\
PKH2 & $\mathrm{MW} 5-10 \mathrm{kDa}$ & $0.329 \pm 0.007^{\mathrm{d}}$ \\
PKH3 & $\mathrm{MW} 3-5 \mathrm{kDa}$ & $0.136 \pm 0.004^{\mathrm{c}}$ \\
PKH4 & $\mathrm{MW}<3 \mathrm{kDa}$ & $0.082 \pm 0.003^{\mathrm{b}}$ \\
Captopril & & $1.62710^{-6} \pm 4.24810^{-8 \mathrm{a}}$ \\
\hline
\end{tabular}

Different letters represent significant difference $(\mathrm{P}<0.01)$ in $\mathrm{IC}_{50}$ values

\subsection{PKHs inhibit ACE in a non-competitive way}

After ACE inhibitory activity of PKHs were demonstrated, next the patterns of this inhibition by Lineweaver-Burk plots in the presence and absence of PKH3 and PKH4 were assessed. As illustrated in Figure 3A, in the presence of 0.1 and $0.2 \mathrm{mg} \mathrm{ml}^{-1}$ of PKH3, all lines intersected at the same $\mathrm{x}$-axis intercept, while they had different $\mathrm{y}$-axis intercepts and slopes, which indicated that PKH3 was most likely a non-competitive inhibitor of ACE. Figure 3B shows a similar result for PKH4. The enzymatic reaction constant $\mathrm{K}_{\mathrm{m}}$ values were similar in the presence of different concentrations of PKH3 and PKH4 (Table 2), but the maximum velocity $\mathrm{V}_{\mathrm{m}}$ decreased with the increasing concentration of PKH3 and PKH4. These data suggested that both PKH3 and PKH4 could bind to ACE non-active sites as well as to the enzymesubstrate complex (AsoodeH et al., 2014). Similarly, peptides from Chinese soy paste (LI et al., 2015) and flaxseed protein peptides (UDENIGWE et al., 2009) were non-competitive ACE inhibitors. Moreover, competitive type (SETAYESH-MeHr \& AsOodeH, 2017) and mixed-type (WANG et al., 2018) of ACE inhibitory mechanisms have been reported as well.

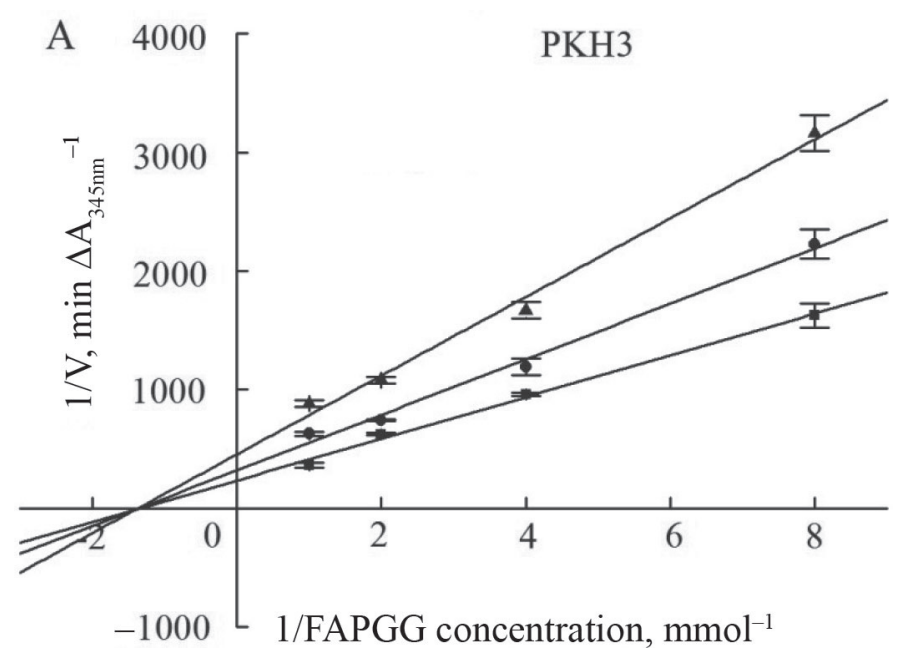

Fig. 3A. Lineweaver-Burk plots of the Angiotensin converting enzyme inhibition at different concentrations of PKH3. The concentrations of PKH3 were $0.0,0.1$, and $0.2 \mathrm{mg} \mathrm{m}^{-1}$

ㅁ: $0.0 \mathrm{mg} \mathrm{ml}^{-1} ; \bullet: 0.1 \mathrm{mg} \mathrm{ml}^{-1} ; \mathbf{\Delta}: 0.2 \mathrm{mg} \mathrm{ml}^{-1}$; 


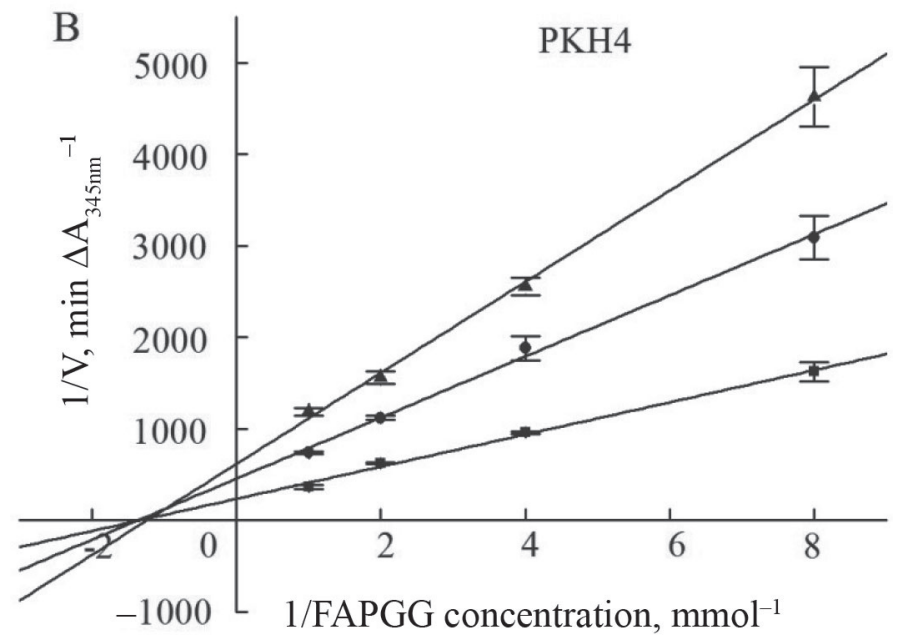

Fig. 3B. Lineweaver-Burk plots of the Angiotensin converting enzyme inhibition at different concentrations of PKH4. The concentrations of PKH4 were $0.0,0.1$, and $0.2 \mathrm{mg} \mathrm{ml}^{-1}$

ㅁ: $0.0 \mathrm{mg} \mathrm{ml}^{-1} ; \bullet: 0.1 \mathrm{mg} \mathrm{ml}^{-1} ; \mathbf{\Delta}: 0.2 \mathrm{mg} \mathrm{m}^{-1}$;

Table 2. Kinetic constants of enzyme-catalyzed reactions at different PKH3 and PKH4 concentrations

\begin{tabular}{llccccc}
\hline \multirow{2}{*}{$\begin{array}{l}\text { Catalytic } \\
\text { parameter }\end{array}$} & Control & \multicolumn{2}{c}{ PKH3 $\left(\mathrm{mg} \mathrm{ml}^{-1}\right)$} & & \multicolumn{2}{c}{ PKH4 $\left(\mathrm{mg} \mathrm{ml}^{-1}\right)$} \\
\cline { 3 - 4 } & & 0.1 & 0.2 & & 0.1 & 0.2 \\
\hline $\mathrm{K}_{\mathrm{m}}(\mathrm{mM})$ & $0.7507 \pm 0.1030^{\mathrm{a}}$ & $0.7331 \pm 0.0845^{\mathrm{a}}$ & $0.7310 \pm 0.0664^{\mathrm{a}}$ & & $0.7368 \pm 0.1215^{\mathrm{a}}$ & $0.8183 \pm 0.1543^{\mathrm{a}}$ \\
$\mathrm{V}_{\mathrm{m}}\left(\Delta \mathrm{A} \mathrm{min}{ }^{-1}\right)$ & $0.0043 \pm 0.0008^{\mathrm{c}}$ & $0.0031 \pm 0.0001^{\mathrm{b}}$ & $0.0022 \pm 0.0001^{\mathrm{ab}}$ & & $0.0022 \pm 0.0001^{\mathrm{ab}}$ & $0.0016 \pm 0.0002^{\mathrm{a}}$ \\
$\mathrm{CE}$ & $0.0057 \pm 0.0005^{\mathrm{d}}$ & $0.0043 \pm 0.0003^{\mathrm{c}}$ & $0.0030 \pm 0.0002^{\mathrm{b}}$ & & $0.0030 \pm 0.0003^{\mathrm{b}}$ & $0.0020 \pm 0.0002^{\mathrm{a}}$ \\
$\mathrm{K}_{\mathrm{i}}\left(\mathrm{mg} \mathrm{ml}^{-1}\right)$ & & \multicolumn{2}{c}{$0.2166 \pm 0.0058$} & & $0.1089 \pm 0.0111^{* *}$ \\
\hline
\end{tabular}

Different letters represent significant difference in same catalytic parameter $(\mathrm{P}<0.01) * *$ represents significant difference in $\mathrm{K}_{\mathrm{i}}$ value $(\mathrm{P}<0.01)$

The catalytic efficiency (CE) of ACE catalytic reaction in the absence of inhibitor was 0.0057, which declined with the increasing concentration of PKH3 or PKH4 (Table 2). The decreases of $\mathrm{CE}$ were in agreement with their respective $\mathrm{V}_{\mathrm{m}}$ and $\mathrm{IC}_{50}$ values for $\mathrm{PKH} 3$ and PKH4.

The inhibition constant $\left(\mathrm{K}_{\mathrm{i}}\right)$ is defined as the affinity of inhibitor to the enzyme in order to form the enzyme-inhibitor complex, and a lower $\mathrm{K}_{\mathrm{i}}$ value indicates a higher affinity activity. As listed in Table 2, the $\mathrm{K}_{\mathrm{i}}$ values were 0.2166 and 0.1089 for PKH3 and PKH4, respectively, indicating that $\mathrm{PKH} 4$ would have higher binding affinity than PKH3 to ACE. The $\mathrm{K}_{\mathrm{i}}$ value of PKH4 was higher than that of the peptides from gluten hydrolysate $\left(0.036 \mathrm{mg} \mathrm{ml}^{-1}\right)$ (AsoODEH et al., 2014). Whereas, the $\mathrm{K}_{\mathrm{i}}$ value of PKH4 was similar to that of Ile-Pro-Ala-Leu-Leu-LysArg from gluten hydrolysate $\left(0.100 \mathrm{mg} \mathrm{ml}^{-1}\right)$ and lower than that of the sea cucumber collagen hydrolysates $\left(0.706 \mathrm{mg} \mathrm{ml}^{-1}\right)$ (LiU et al., 2011). 


\subsection{Amino acid compositions}

The amino acid compositions and amounts of PKHs were determined and the data are presented in Table 3. The PKH4 had high levels of Ser, Ala, Met, Leu, Tyr, Phe, Arg, and Trp than other fractions. Compared with other PKHs, PKH4 had higher levels of hydrophobic amino acids (HAAs) (32.76 \%) and aromatic amino acids (AAAs) (11.03\%). ARISE and coworkers (2017) reported that peptides with high HAAs and AAAs levels had high anti-ACE activity. Study from MAHMOODANI and co-workers (2014) also showed that the high anti-ACE activities of catfish skin and bone gelatine hydrolysates came with higher level of HAAs. Thus, the amount of HAAs and AAAs were responsible for the anti-ACE activity of PKHs. In addition, the level of branched-chain amino acids (BCAAs) was highly elevated in PKH4 (13.95\%, Table 3).

Table 3. Amino acid composition and levels of PKHs, g/100 g protein/dw

\begin{tabular}{|c|c|c|c|c|c|}
\hline Amino acid & PKH & PKH1 & PKH2 & РKH3 & PKH4 \\
\hline Asp & $11.04 \pm 0.01^{\mathrm{b}}$ & $12.44 \pm 0.05^{\mathrm{a}}$ & $11.18 \pm 0.01^{\mathrm{b}}$ & $8.72 \pm 0 . .09^{c}$ & $7.66 \pm 0.16^{\mathrm{d}}$ \\
\hline Thr & $2.10 \pm 0.09^{\mathrm{b}}$ & $2.22 \pm 0.04^{\mathrm{ab}}$ & $2.18 \pm 0.03^{\mathrm{ab}}$ & $2.25 \pm 0.01^{\mathrm{ab}}$ & $2.35 \pm 0.06^{\mathrm{a}}$ \\
\hline Ser & $3.76 \pm 0.09^{\mathrm{c}}$ & $3.62 \pm 0.11^{\mathrm{c}}$ & $3.69 \pm 0.00^{\mathrm{c}}$ & $4.04 \pm 0.01^{\mathrm{b}}$ & $4.56 \pm 0.02^{\mathrm{a}}$ \\
\hline Glu & $31.39 \pm 0.16^{\mathrm{c}}$ & $30.75 \pm 0.06^{\mathrm{c}}$ & $32.81 \pm 0.15^{\mathrm{b}}$ & $34.69 \pm 0.16^{\mathrm{a}}$ & $30.66 \pm 0.33^{c}$ \\
\hline Pro & $3.97 \pm 0.05^{\mathrm{a}}$ & $4.08 \pm 0.16^{\mathrm{a}}$ & $3.85 \pm 0.31^{\mathrm{a}}$ & $3.87 \pm 0.12^{\mathrm{a}}$ & $2.60 \pm 0.13^{\mathrm{b}}$ \\
\hline Gly & $5.23 \pm 0.10^{\mathrm{b}}$ & $5.19 \pm 0.03^{b}$ & $5.46 \pm 0.07^{\mathrm{ab}}$ & $5.75 \pm 0.12^{\mathrm{a}}$ & $5.41 \pm 0.15^{\mathrm{ab}}$ \\
\hline Ala & $3.63 \pm 0.09^{\mathrm{b}}$ & $3.58 \pm 0.07^{\mathrm{b}}$ & $3.45 \pm 0.02^{\mathrm{b}}$ & $3.40 \pm 0.11^{\mathrm{b}}$ & $4.03 \pm 0.10^{\mathrm{a}}$ \\
\hline Cys & $0.60 \pm 0.21^{\mathrm{a}}$ & $0.57 \pm 0.18^{\mathrm{a}}$ & $0.50 \pm 0.35^{\mathrm{a}}$ & $0.55 \pm 0.01^{\mathrm{a}}$ & $0.18 \pm 0.01^{\mathrm{a}}$ \\
\hline Val & $3.81 \pm 0.03^{\mathrm{ab}}$ & $3.95 \pm 0.03^{\mathrm{a}}$ & $3.67 \pm 0.04^{\mathrm{b}}$ & $3.63 \pm 0.00^{\mathrm{b}}$ & $3.78 \pm 0.13^{\mathrm{ab}}$ \\
\hline Met & $0.73 \pm 0.06^{\mathrm{b}}$ & $0.41 \pm 0.01^{\mathrm{c}}$ & $0.72 \pm 0.04^{\mathrm{b}}$ & $0.94 \pm 0.01^{\mathrm{ab}}$ & $0.98 \pm 0.11^{\mathrm{a}}$ \\
\hline Ile & $3.06 \pm 0.03^{\mathrm{a}}$ & $2.91 \pm 0.11^{\mathrm{a}}$ & $2.94 \pm 0.12^{\mathrm{a}}$ & $2.97 \pm 0.00^{\mathrm{a}}$ & $3.14 \pm 0.02^{\mathrm{a}}$ \\
\hline Leu & $6.30 \pm 0.02^{b}$ & $6.59 \pm 0.01^{\mathrm{b}}$ & $5.99 \pm 0.07^{\mathrm{c}}$ & $5.74 \pm 0.05^{\mathrm{c}}$ & $7.03 \pm 0.14^{\mathrm{a}}$ \\
\hline Tyr & $2.51 \pm 0.12^{\mathrm{b}}$ & $2.48 \pm 0.02^{\mathrm{b}}$ & $2.15 \pm 0.15^{\mathrm{b}}$ & $2.69 \pm 0.08^{b}$ & $3.88 \pm 0.32^{\mathrm{a}}$ \\
\hline Phe & $4.68 \pm 0.05^{\mathrm{b}}$ & $4.89 \pm 0.08^{\mathrm{ab}}$ & $4.49 \pm 0.03^{\mathrm{b}}$ & $4.23 \pm 0.47^{\mathrm{b}}$ & $6.01 \pm 0.52^{\mathrm{a}}$ \\
\hline His & $2.76 \pm 0.22^{\mathrm{a}}$ & $2.27 \pm 0.14^{\mathrm{a}}$ & $2.60 \pm 0.13^{\mathrm{a}}$ & $2.51 \pm 0.06^{\mathrm{a}}$ & $2.31 \pm 0.42^{\mathrm{a}}$ \\
\hline Lys & $1.69 \pm 0.01^{\mathrm{ab}}$ & $1.59 \pm 0.02^{\mathrm{b}}$ & $1.83 \pm 0.08^{\mathrm{a}}$ & $1.75 \pm 0.03^{\mathrm{ab}}$ & $1.78 \pm 0.08^{\mathrm{ab}}$ \\
\hline Arg & $11.80 \pm 0.04^{\mathrm{b}}$ & $11.66 \pm 0.09^{b}$ & $11.88 \pm 0.08^{\mathrm{ab}}$ & $11.56 \pm 0.08^{\mathrm{b}}$ & $12.54 \pm 0.37^{\mathrm{a}}$ \\
\hline Trp & $1.00 \pm 0.01^{\mathrm{b}}$ & $0.85 \pm 0.03^{\mathrm{c}}$ & $0.65 \pm 0.05^{\mathrm{d}}$ & $0.74 \pm 0.03^{\mathrm{cd}}$ & $1.15 \pm 0.02^{\mathrm{a}}$ \\
\hline HAAs & $30.26 \pm 0.29^{b}$ & $30.29 \pm 0.07^{\mathrm{b}}$ & $28.39 \pm 0.05^{\mathrm{c}}$ & $28.74 \pm 0.39^{\mathrm{c}}$ & $32.76 \pm 0.44^{\mathrm{a}}$ \\
\hline BCAAs & $13.17 \pm 0.02^{b c}$ & $13.44 \pm 0.07^{\mathrm{ab}}$ & $12.60 \pm 0.24^{\mathrm{cd}}$ & $12.34 \pm 0.05^{\mathrm{d}}$ & $13.95 \pm 0.24^{\mathrm{a}}$ \\
\hline PCAAs & $16.25 \pm 0.17^{\mathrm{a}}$ & $15.51 \pm 0.21^{\mathrm{a}}$ & $16.30 \pm 0.12^{\mathrm{a}}$ & $15.82 \pm 0.01^{\mathrm{a}}$ & $16.63 \pm 0.86^{\mathrm{a}}$ \\
\hline NCAAs & $42.43 \pm 0.16^{\mathrm{b}}$ & $43.18 \pm 0.01^{\mathrm{ab}}$ & $43.99 \pm 0.13^{\mathrm{a}}$ & $43.41 \pm 0.25^{\mathrm{ab}}$ & $38.32 \pm 0.49^{c}$ \\
\hline AAAs & $8.18 \pm 0.07^{\mathrm{b}}$ & $8.21 \pm 0.06^{\mathrm{b}}$ & $7.28 \pm 0.23^{b}$ & $7.66 \pm 0.53^{b}$ & $11.03 \pm 0.82^{\mathrm{a}}$ \\
\hline
\end{tabular}

dw: dry weight. Different superscript letters in the same row mean statistical differences between samples $(\mathrm{P}<0.01)$. HAAs: hydrophobic amino acids (Pro, Ala, Val, Met, Ile, Leu, Tyr, Phe, Trp, and Cys); BCAAs: branched-chain amino acids (Val, Ile, and Leu). PCAAs: positively charged amino acids (Arg, His, and Lys); NCAAs: negatively charged amino acids (Asp and Glu); AAAs: aromatic amino acids (Phe, Trp, and Tyr) 
Some reports suggested that the presence of BCAAs enhances anti-ACE activity of peptides such as chicken skin protein hydrolysates (ONUH et al., 2015) and seaweed peptides (CIAn et al., 2015). Furthermore, the amounts of Glu and Asp were high in all PKHs. Glu and Asp belong to negatively charged amino acids (NCAAs), which can participate in ionic interaction with metal cations. It is well known that ACE is a metallo-carboxy peptidase with zinc binding site. Our data showed that all PKHs possessed high level of Glu and Asp, and the percentage reached around $40 \%$ (Table 3 ). Thus, the amino acid levels of HAAs, AAAs, and BCAAs affected the ACE inhibitory activity of peptides.

\section{Conclusions}

The PKHs had ACE inhibitory activity with their $\mathrm{IC}_{50}$ values negatively correlating with the sizes of the PKHs. The lowest molecular weight peptide fraction (PKH4) had the highest ACE inhibitory activity and the lowest $\mathrm{IC}_{50}$ value. Lineweaver-Burk plots revealed that both PKH3 and PKH4 were non-competitive ACE inhibitors. PKH4 contained higher levels of HAAs, AAAs, and BCAAs than other PKHs, and this may account for its high ACE inhibitory activity. In future, it would be interesting to identify the sequences of the peptides with high ACE inhibitory activity and to test their function in animal model or clinic trials for disease control.

This work was financially supported by the project of Science and Technology Department of Tibet of China (Z2016B01N04). We would like to express our sincere gratitude to Professor Cao for professional advice on writing and revision.

\section{References}

Arise, A.K., Alashi, A.M., Nwachukwu, I.D., Malomo, S.A., Aluko, R.E. \& Amonsou, E.O. (2017): Inhibitory properties of bambara groundnut protein hydrolysate and peptide fractions against angiotensin-converting enzymes, renin and free radicals. J. Sci. Food Agr., 97, 2834-2841.

Asoodeh,A.,Haghighi,L., Chamani, J.,Ansari-OgholbeyK, M.A., Mojallal-Tabatabaei,Z.\&LagZian, M.(2014): Potential angiotensin I converting enzyme inhibitory peptides from gluten hydrolysate: Biochemical characterization and molecular docking study. J. Cereal Sci., 60, 92-98.

Betancur-Ancona, D., Davila-Ortiz, G., Chel-Gerrero, L.A. \& Torruco-Uco, J.G. (2015): ACE-I inhibitory activity from Phaseolus lunatus and Phaseolus vulgaris peptide fractions obtained by ultrafiltration. J. Med. Food, 18, 1247-1254.

Bidlingmeyer, B.A., Cohen, S.A. \& TARvin, T.L. (1984): Rapid analysis of amino acids using pre-column derivatization. J. Chromatogr. B., 336, 93-104.

CAssiem, W. \& De Kock, M. (2019): The anti-proliferative effect of apricot and peach kernel extracts on human colon cancer cells in vitro. BMC Complem. Altern. M., 19, 32.

Cian, R.E., Garz, N.A.G., Ancona, D.B., Guerrero, L.C. \& Drago, S.R. (2015): Hydrolyzates from Pyropia columbina seaweed have antiplatelet aggregation, antioxidant and ACE I inhibitory peptides which maintain bioactivity after simulated gastrointestinal digestion. LWT-Food Sci. Technol., 64, 881-888.

Collins, K.G., Fitzgerald, G.F., Stanton, C. \& Ross, R.P. (2016): Looking beyond the terrestrial: The potential of seaweed derived bioactives to treat non-communicable diseases. Mar. Drugs, 14, 60-91.

Girgih, A.T., He, R. \& Aluko, R.E. (2014): Kinetics and molecular docking studies of the inhibitions of angiotensin converting enzyme and renin activities by hemp seed (Cannabis sativa L.) peptides. J. Agr. Food Chem., 62, 4135-4144.

Iordănescu, O., Alexa, E., Radulov, I., Costea, A., Dobrei, A. \& Dobrei, A. (2015): Minerals and amino acids in peach (Prunus persica L.) cultivars and hybrids belonging to world germoplasm collection in the conditions of west Romania. Agric. Agric. Sci. Proc., 6, 145-150. 
LAEMMLI, U.K. (1970): Cleavage of structural proteins during the assembly of the head of bacteriophage T4. Nature. 227, 680-685.

Li, F., Yamaki, K., Cheng, Y. \& Fang, Y. (2015): Assessment and separation of angiotensin I-converting enzyme inhibitory peptides in Chinese soypaste. Int. J. Food Eng., 11, 301-305.

LiU, Z., Chen, D., Su, Y. \& ZeNG, M. (2011): Optimization of hydrolysis conditions for the production of the angiotensin-I converting enzyme inhibitory peptides from sea cucumber collagen hydrolysates. J. Aquat. Food Prod. T., 20, 222-232.

Lombard, J.H. \& Delange, D.J. (1965): The chemical determination of tryptophan in foods and mixed diets. Anal. Biochem., 10, 260-265.

Luna-Vital, D.A., Gonzalez de Mejia, E., Mendoza, S. \& Loarca-Pina, G. (2015): Peptides present in the nondigestible fraction of common beans (Phaseolus vulgaris L.) inhibit the angiotensin-I converting enzyme by interacting with its catalytic cavity independent of their antioxidant capacity. Food Funct., 6, 1470-1479.

Luo, J., Zhang, C., Liu, Q., Ou, S., Zhang, L. \& Peng, X. (2017): Combinative effect of sardine peptides and quercetin alleviates hypertension through inhibition of angiotensin I converting enzyme activity and inflammation. Food Res. Int., 100, 579-585.

Mahmoodani, F., Ghassem, M., Babji, A.S., Yusop, S.M. \& Khosrokhavar, R. (2014): ACE inhibitory activity of pangasius catfish (Pangasius sutchi) skin and bone gelatin hydrolysate. J. Food Sci. Tech., 51, 1847-1856.

Mirzapour, M., Rezaei, K. \& Sentandreu, M.A. (2017): Identification of potent ACE inhibitory peptides from wild almond proteins. J. Food Sci., 82, 2421-2431.

Onuh, J.O., Girgih, A.T., Malomo, S.A., Aluko, R.E. \& Aliani, M. (2015): Kinetics of in vitro renin and angiotensin converting enzyme inhibition by chicken skin protein hydrolysates and their blood pressure lowering effects in spontaneously hypertensive rats. J. Funct. Foods, 14, 133-143.

Rafiq, S., Huma, N., Pasha, I., Shahid, M. \& Xiao, H. (2017): Angiotensin-converting enzyme-inhibitory and antithrombotic activities of soluble peptide extracts from buffalo and cow milk cheddar cheeses. Int. J. Dairy Technol., 70, 380-388.

Setayesh-Mehr, Z. \& Asoodeh, A. (2017): The inhibitory activity of hl-7 and hl-10 peptide from scorpion venom (Hemiscorpius lepturus) on angiotensin converting enzyme: Kinetic and docking study. Bioorg. Chem., 75, 30-37.

Shobako, N., Ogawa, Y., Ishikado, A., Harada, K., KobaYashi, E., ... . \& Ohinata, K. (2018): Anovel antihypertensive peptide identified in thermolysin-digested rice bran. Mol. Nutr. Food Res., 62, 1700732.

Udenigwe, C.C., Lin, Y., Hou, W. \& Aluko, R.E. (2009): Kinetics of the inhibition of renin and angiotensin I-converting enzyme by flaxseed protein hydrolysate fractions. J. Funct. Foods, 1, 199-207.

Wang, C., Tu, M., Wu, D., Chen, H., Chen, C., Wang, Z. \& Jiang, L. (2018): Identification of an ACE-inhibitory peptide from walnut protein and its evaluation of the inhibitory mechanism. Int. J. Mol. Sci., 19, 1156-1166.

Wang, H., Zhang, L. \& FU, Y. (2015): Analysis on clinical dosage of taoren (Semen persicae) in the past dynasties. J. Tradit. Chin. Med., 56, 68-71. (in Chinese)

Yi, M., Deng, J., HaO, E., Ye, X., WAng, J. \& Du, Z. (2013): Pharmacodynamic effects of Persicae semen extract on blood circulation disorder of rats induced by different symptoms. Chinese Traditional and Herbal Drugs, 44, 858-862. (in Chinese)

Zhu, Z., YANG, M., Yi, J. \& WANG, L. (2015): Study on enzymatic hydrolysis conditions for the preparation of dual rennin and ACE inhibitory peptide from peach kernel protein isolate. Journal of Shanxi University of Science \& Technology. 33, 116-120. (in Chinese) 